\title{
From Private to Public Evil: or from the 'wicked woman' in Arden of Faversham to Alexander Goehr's Opera Arden must Die
}

Christa Jansohn

\section{(2) OpenEdition \\ Journals}

Electronic version

URL: http://journals.openedition.org/shakespeare/1143

DOI: 10.4000/shakespeare.1143

ISSN: 2271-6424

Publisher

Société Française Shakespeare

Printed version

Date of publication: 1 November 1997

Number of pages: 59-76

\section{Electronic reference}

Christa Jansohn, « From Private to Public Evil: or from the 'wicked woman' in Arden of Faversham to Alexander Goehr's Opera Arden must Die », Actes des congrès de la Société française Shakespeare [Online], 15 | 1997, Online since 01 January 2007, connection on 22 April 2019. URL : http:// journals.openedition.org/shakespeare/1143; DOI : 10.4000/shakespeare.1143 


\section{F R O M P R I V A T E T T P P B L I C E V I L : O R F R O M T H E I N ARDE $O$ OF FAVERSHAM T O A L EX A N D E R G O E H R'S O P E R A A R D E N MUST D IE}

When in 1621 John Taylor prophesied that the bloody murder of Arden of Faversham would never be forgotten, he could hardly foresee how right he was ${ }^{1}$. Since the actual committing of the deed, in 1551 , the spectacular crime seems to have remained fresh in men's memory, as the numerous versions demonstrate. Among them, The Lamentable and True Tragedy of Master Arden of Faversham, written in 1592, is without doubt the most famous account of the murder, yet we should not forget the considerable number of other versions of it, in chronicles, pamphlets, homilies, ballads and, not least, the opera Arden must Die by the British composer Alexander Goehr, which had its premiere in Germany in 1967. Only two years later, an American novelist, Diane Davidson, made once more use of the same plot in her nove Arden of Faversham and, again, in 1982 the German poet Erich Fried wrote another play, called ... And all his murderers, mainly based on his libretto for Goehr's opera, but with interesting changes in its approach to the problem of how evil is to be treated in this play. Finally, one could mention three different versions by the Swiss poet Jurg Laederach who again uses a fresh approach to the old story, characterized by the anonymous play as the case of Arden . Following this appetiser, the title-page further describes the play,.

What I should like to do in this paper is to investigate the different motives behind the various literary versions of this evil crime rather than the presentation of the actual murder ${ }^{2}$. None of the authors seem to be primarily interested in the metaphysical conflict between Good and Evil or in Lear's agonised question (III.6.76-7), but rather in some particular moral, didactic or 
political message.

: Contemporary Motives for Retelling the Story of the Murder

To account for the story's reception by later authors and their audiences, it is important to inquire into their motives for retelling an episode most of them took from Holinshed, the anonymous play, or other contemporary accounts. In the , published in $1633^{3}$, the story of the murder is recounted in the form of a self-accusing soliloquy, keeping closely but not slavishly to the events in the play. At the end, the repentant Alice asks for mercy and prays to God to save us from all evil :

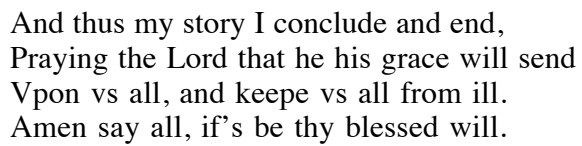

(II.189-92, Wine, p. 170) ${ }^{4}$

These concluding lines of the ballad, with their unmistakable echo of the Lord's Prayer () confirm that, on the whole, the intention is not so much a didactic, as in the tragedy of that title or several other ballads of the time, such as $(1628)^{5}$, but rather, as the title suggests, a , the confession of a penitent and converted sinner, truly sorry for her misdeed and all the circumstances surrounding it :

Ay me, vile wretch, that euer I was borne,

Making my selfe vnto the world a scorne :

And to my friends and kindred all a shame,

Blotting their blood by my vnhappy name.

(II.1-4, Wine, p. 164)

It is interesting to note that this ballad of 192 lines is the only version of the crime told from the murderess' point of view and in her own words. It is probably for this reason that the social and economic aspects of the incident that play such a large part in the anonymous play are omitted, as are the unsuccessful, bumbling attempts of the two villains to take Arden's life. Instead, the author of the ballad directs all his and the reader's attention at the character of Alice. She describes her part in the story as (1.13), but, especially at the beginning of the poem, she puts the blame not so much on herself as on Mosbie, who with his destroyed her apparently untroubled, happy and peaceful marriage (1. 5-9). In contrast, Holinshed, as well as the play, portrays her from the beginning as no less active and lewd than Mosbie, 
and it is she in the end, who regains the affection of her lover with a pair of silver dice (1.122-25). In the ballad, these motives as well as the constant quarrels between the two lovers are passed over and all we are given is an impression of a rather sensuous relationship (, 1.118), pushing her by degrees towards the murder: (1. 140). This is all she has to say immediately before the crime, which is planned (1.145) and executed by all the murderers.

In Holinshed's chronicle, the story of the murder is discussed on an entirely different plane and the intentions behind the whole account are not the same as in the play or the ballad. Though Holinshed discusses the case in some detail and with genuine interest and though he insists on the authenticity of his sources, he appears to be in some doubt as to whether this private affair rightly belongs into a chronicle ; after devoting over five pages to it (p. 1703-1708 in the first edition) he resumes his narrative of historical events (); the only other item worth recording for the year 1551 concerns the effects of the (p. 1708).

To justify his long digression on the murder of Arden Holinshed immediately supplies a - to my mind rather lame - reason in the atrociousness of the evil deed that needs to be recorded :

The which murther, for the horribleness thereof, although otherwise it may seeme to be but a priuate matter, and therefore as it were impertinent to this historie, I haue thought good to set it foorth somewhat at large, hauing the instructions deliuered to me by them, that haue vsed some diligence to gather the true vnderstanding of the circumstances.

(Wine, p. 148)

It is easy to see from other parts of Holinshed's account that this emotiona description of the crime does not in any way stand out from his habitual chronicle style since he repeatedly introduces episodes of this kind, thereby disregarding the rigid conventions of traditional res gestae. Annabel Patterson calls these digressions, defining them as ${ }^{6}$, though she explicitly excludes the murder of Arden from her list of paradigmatic anecdotes, because for her only the stories about William Rufus, the flood disaster of north-east England and Woolf's treatise on as are really representative of the history of England ; they alone stand for (Patterson, p. 44).

To my mind, however, the murder of Arden is an essential part of this history ; it is used above all as an instance of the re-establishing of sociopolitical order, by showing the evil consequences of a criminal relationship in which the woman refuses to accept the part alotted her by nature. Thus the natural marital relation as a microcosm can be a threat to the social and 
political macrocosm since, after all, men are, as Richard Hooker says in $O f$ the Laws of Ecclesiastical Policy (1593); accordingly, the husband should be , the wife as Dod and Cleaver put it (1598) ${ }^{7}$, Henry Smith calls her $(1591)^{8}$, and a disharmonious marriage is compared to a divided kingdom : 9 . Shakespeare also makes use of this commonplace of marital union as political microcosm in his comedy The Taming of the Shrew, though he significantly departs from an exclusively biblical interpretation ${ }^{10}$.

In Arden of Faversham, too, the author employs a political terminology when portraying Alice's criticism of her marriage with Arden. Her rebellion seems equally directed against her passive role as a wife and against what she sees as an illegitimate swallowing up of her personality within the marriage contract :

And he [Arden] usurps it, having nought but this,

That I am tied to him by marriage.

Love is a god, and marriage is but words.

$\left(\right.$ I.99-101) ${ }^{11}$

From Arden's point of view, Mosbie's is closely related to his own acquisitive business practice :

As for the land, Mosby, they are mine
By letters patents from his majesty.
But I must have a mandate for my wife ;
They say you seek to rob me of her love

$(\mathrm{I} .300-304)^{12}$

Alice's behaviour and her moral depravation are deeply rooted in her desire for emancipation, which makes her totally blind to the social reality : all she can actually have hoped to gain is the exchange of one kind of dependence for another. The anonymous dramatist leaves us in no doubt about this dilemma when on the one hand he makes Alice ask, (X.83-85), and on the other lets her lover early on speculate about the possibility of a new union with the provision, thou'lt be ruled by me (I.224).

The examples from contemporary documents confirm that the relation between the genders is frequently associated with political power-structures ; thus, private and public affairs clearly have more in common than is suggested by Holinshed's pseudo-problem, . This, like the other episodes about women inserted into the chronicle account ${ }^{13}$, was easily pressed into the service of a general social message and made an exemplum, as is particularly well demonstrated by the story of Elizabeth Shore ${ }^{14}$. 
In other contemporary annals and chronicles, the murder is recorded simply as a sensational news item; this, of course, did not produce the same profound impression as The Chronicles of England, Scotland, and Ireland, whose account inspired poetic versions and whose authority is adduced by other authors, e.g. Henry Goodcole in (1635) :

I will only remember you of Mistress Arden, who caused her husband to be murdered in her own house at Feversham in Kent, the memorable circumstances thereof deserving places in a most approved chronicle, may be very well spared in this short discourse ${ }^{15}$.

Holinshed's version is used once more, as late as 1897 , by Abe $\mathrm{H}$. Coppinger, along with excerpts from the play, in his anthology Twelve Bad Women, with the remarkable subtitle ${ }^{16}$. According to Coppinger, modern research has but little to add to this reliable historical source (p. 33). Though the collection is meant as a companion to Thomas Secombé's Lives of Twelve Bad Men. Original Studies of Eminent Scoundrels by Various Hands (London, 1894), its thoroughly antifeminist bias is manifest from the subtitle, the preface, and the motto, added to the second edition, taken from Thomas Otway :

... the purpose is to give unvarnished accounts of twelve women of whom enough is known to show that they were consistently bad, whether owing to a vicious temperament, a crooked nature, or a lack of moral perception, resulting in unscrupulousness and crime.

(Preface, $x$ iii) ${ }^{17}$

The list of the chief attributes of these Twelve Bad Women, has much in common with the catalogues of ill-reputed women in medieval sermons or other literary texts ${ }^{18}$. The murder, however, in this volume, seems to be presented merely as a, (p. xiii) and has very little in common with Holinshed's socio-political purpose.

My brief survey will perhaps have made clear that the overall intentions of the various authors who include this murder-case among their own account differ greatly. It is worth noting that Alice's crime appears as one of a series of murder-stories dealing with wives who made away their husbands, published in remarkable numbers between 1590 and 1630. The reason for this vogue has evidently to do with a surge of and in a more sceptical attitude 
towards the institution of marriage ${ }^{19}$. Alice's almost epigrammatic remark, (I.101) seems to be symptomatic of this changed view of marriage, which, in turn, inevitably provoked a number of literary and historical texts, and even more, sermons in reply. However, it needs stressing that the anonymous play, apart from its subtitle, refrains from an explicit moral :

Gentlemen, we hope you'll pardon this naked tragedy

Wherein no filèd points are foisted in

To make it gracious to the ear or eye :

For simple truth is gracious enough

And needs no other points of glozing stuff.

(Epilogue, 14-18)

What seems more important, though, is the fact that within the play itself the individual characters are presented altogether in a much less prejudiced and one-dimensional manner and not held up as objects of moral lessons, as in Holinshed and in the ballad. The reader (not necessarily the audience in the theatre) is offered a much more ambiguous and many-facetted view of the events than in most other contemporary accounts. This may be the reason for the astonishing number of adaptations, extracting new interpretations from this seemingly unbiased, dramatic version.

Alexander Goehr's Opera Arden Must Die (1967)

Alexander Goehr's opera Arden Must Die, based on the libretto by the German author Erich Fried, is certainly one of the most original modern versions of the Elizabethan murder story. Composer and poet deliberately set out to confront the more traditional operatic scene with fresh ideas and musical forms. It was the first opera of the 34-year-old composer, whose artistic development had been formed decisively by his studies with Olivier Messiaen and who had up to then produced mainly chamber music, songs, cantatas and orchestral works; he is considered head of the moderately modernist Manchester school. Erich Fried, on the other hand, had already made a name for himself as translator of T. S. Eliot, Dylan Thomas and Shakespeare.

The opera, commissioned by the artistic director of the Hamburg State Opera, Rolf Liebermann, was first performed on 5 March 1967 (directed by Egon Monk ; conductor: Charles Mackerras) ; the first English performance by the New Opera Company at Saddler's Wells, London, took place on 17 April 1974 (directed by Jonathan Miller ; conductor : Meredith Davies); the libretto was translated by Geoffrey Skelton.

The idea of an opera based on the anonymous play Arden of Faversham apparently came from Alexander Goehr's wife, Audrey as well as from the 
composer himself who first encountered the play in the B.B.C. on 29 January $1962^{20}$. What Goehr originally had in mind was a musical adaptation of The Yorkshire Tragedy, and when he decided on Arden of Faversham, he had at first plans for a very different, rather darker treatment, with Alice Arden at the centre. It was to be a more naturalistic, bourgeois opera, a Lady Macbeth of the Fields, not a political piece, such as Erich Fried eventually laid before him $^{21}$.

The quality of a libretto never depends on its literary, but rather on its value, that is, «its ability to leave the essential message to the music, to stimulate it into exploiting all its expressive potentialities, without dispensing with an action that is at the same time intelligible and theatrically effective, appealing to the minds and the senses of the listeners ${ }^{22}$. To meet these demands, the libretto must have very specific stylistic, dramaturgic and scenic qualities ${ }^{23}$; they are described by Erich Fried in the programme notes for the German production :

Since the libretto took over or adapted the characters of the old play, yet treated them throughout in the manner of a morality play, these characters became didactic, just as in a morality play. Arden's proud arrogance towards the poor devils Reede and Greene, Franklin's moneyed pride devils Reede and Greene, Franklin's moneyed pride
and harsh treatment of his servants, but especially the hypocrisy of the neighbour woman Mrs. Bradshaw (my own invention), keeps protesting that she is against the murderous deed, but at the same time becomes increasingly a party to the guilt, carries messages for the murderers, indeed finds the murderers irresistible - all this should hardly be altogether unfamiliar to an audience of today ${ }^{24}$.

Even this short sketch makes clear that it is another kind of Fried wanted to make the subject of his libretto. He was not so much interested in the figure of and her motives nor did he want to pass moral judgement on her, such as the title of the quarto of 1592 impresses on the reader; rather he places the newly created character of Mrs. Bradshaw at the centre of the action. It is obvious that this person serves Fried to raise the problem of dealing with the past and with our guilt complex, an issue that dominated German political discussions in the early seventies in connection with the Vietnam crisis and the spectre of neo-nazism.

As 25 Mrs Bradshaw plays the innocent neighbour who knows everything but makes no move to prevent the murderers. She is the typical by-stander who does not dare to take any risk or put herself in any possible 
danger. Right at the beginning of the opera, when Alice, Mosbie, Michael and Susan, Greene and Reede as well as Will and Shakesbag form a chorus and sing , Mrs Bradshaw stands opposite and (p. 14) asks for their motives, concluding : The English version is much weaker. It runs :

\author{
What can I hope to do, \\ I, a virtual stranger? \\ Can it be true \\ That Arden's life's in danger? \\ And now the time draws near \\ To meet his dark pursuer. \\ I'd gladly interfere, \\ If I could know for sure \\ Well, then, I'll say no more. \\ I do not sin. \\ When I knock at Heaven's door, \\ I'm sure they'll let me in. \\ And if it's said \\ That I to this deed assented, \\ You know it is a lie : \\ I always was against it !
}

(Vocal score, p. 35-38) ${ }^{26}$

When the deed is done Mrs Bradshaw again assures the audience that . On the other hand, the two lovers Alice and Mosbie pass the dagger from hand to hand while singing a ditty which is a parody of a pseudo-Nazi song, . And finally, even the two ruffians, Black Will and Shakebag, who at first have tried to shuffle off all responsibility for the crime, save their lives by offering their services to the police, who promptly accept them.

By additions such as these, the librettist succeeds in moving the murder story out of the private sphere and put it into a political context. Some reviewers of the English production felt that some insertions were more relevant for a German than for an English audience : «a protest against the neo-Nazis... is of little consequence to an English audience ${ }^{27}$. Due to this more national aspect, the libretto occupies something like a middle position between the domestic tragedy and its source in Holinshed who draws attention to the public relevance of this murder (Wine, p. 148).

Thirty curtain-calls suggest that the Hamburg production was a great success. The frenetic applause, however, was accompanied by vehement booing and hissing from some members of the audience who felt the work to be a political provocation. This was apparently just what Erich Fried had anticipated when at the end of his contribution to the programme notes he 
remarked coolly,

It was evident that spectators and parts of the press were irritated especially by the epilogue, in particular by its concluding lines :

There is one thing that may console you on your way home : you yourself

Are not guilty of any murder nor of any other crimes :

You are neither perpetrators nor accomplices nor such as did not want to know anything about it.

And even if you were such you were not like Alice, in your own home,

But a long way off and much better organised ${ }^{28}$.

The problem of collective guilt as well as of the surmounting of the past as burning issues of recent German history is not a new phenomenon in the work of Erich Fried. It is ever present in his early poetry, in his novel Ein Soldat und ein Mädchen [A Soldier and a Girl], begun in 1946 and elsewhere. The is intended to «make people suddenly see things again they have taken for granted and have even ceased noticing, perhaps by the way we [the artists] show them from an unexpected angle or connect things whose interconnectedness they have not realised ${ }^{29}$. At the same time, Fried emphasised that the libretto was not just a political statement :

It would be a mistake to think that the text is merely an excuse for attack on present-day society. The dramatic character of a text must never be suppressed by its message. So, this is not a libretto à clef, not a forced modern application! The composer and I knew that the whole work and every single scene must be really fun for us. A scene that were tolerable only as a means of conveying music or thought would be a failed scene ${ }^{30}$.

When it comes to the point, however, Fried is opposed to an art that is divorced from reality since, without art's commitment, nothing would be left of the colourful vitality of the world we live in ${ }^{31}$. This political commitment was often, by reviewers of Arden muß sterben, felt to be a wilfully topical gesture, culminating in the unequivocal Vietnam address to the audience, which made one critic head his review with the polemic caption ${ }^{32}$. Other critics described the reactions of the audience as $\left[{ }^{33}\right.$, referring to an organised group of chiefly young members of the audience who protested against the performance by singing the national anthem ${ }^{34}$. Others took the epilogue as a sign of Erich Fried's inexperience as writer of librettos. With his garrulous 
postscript, he finally reveals himself as a newcomer in the opera-business, who wants to stir up comic musical theatre and play the lion at the same time ${ }^{35}$. It was not so much the provocation that was felt to be misplaced, but the moral button-holing gesture of the epilogue which was not only recited with the utmost agitation, but ${ }^{36}$ so that the monologue was doubled into an obtrusive dialogue. Another critic gave this description and explanation :

The spoken words were accompanied, as if from a great distance, by isolated espressivo phrases whose lyricism was as ambiguous as that of Eisler's score for Nuit \& Brouillard. The whispers of a music that appears to be looking the other way somehow carried further than the text's halfsmothered shout of J'accuse! and they made further indictments superfluous ${ }^{37}$.

From a more literary and aesthetic point of view, the epilogue was condemned as which merely added what the play should have shown by itself, so that the formal principles of Brecht had degenerated into purposeless schematism ${ }^{38}$.

Such a verdict hardly agrees with the intentions of the composer and librettist, who wanted to produce a ${ }^{39}$. In this respect, they were more successful in the English production, where the epilogue was cut, but the political themes were still present ${ }^{40}$. Instead of an obtruded moral lesson, it was once more the poetic and musical art that acted as the proper vehicle of Fried's and Goehr's view of society. For a just appreciation of that vehicle we have to take into consideration their view of the situation of the opera ; they evidently regard opera as a form of art with some scepticism :

Could one really today, we asked ourselves, take quite seriously an opera that takes itself quite seriously? Must not an opera, to escape the fate of unconsciously making fun of itself, anticipate that unconscious mockery by deliberately parodying itself, at least in some part, which would make its true seriousness come out all that much more sharply, perhaps even heightened by the contrast ? ${ }^{41}$

By deliberately including elements of parody into their work, Fried and Goehr actually created something like an anti-opera, in which the subject is reflected in the light of the situation of the arts in the seventies. Throughout, then, stylisation, symbolism and cliché are dominant elements in this, though one reviewer expressed some doubt whether the clichés really were all intentional, «especially since the actual realisation is somewhat deficient in logical 
consistency ${ }^{42}$. There seems to be, however, some logic in the very absence of logic, when, for instance, Goehr on the one hand incorporates Orlando Gibbons' London Street Cries in his market scene, but does not, on the other hand, make use of direct quotation, as Fried does so frequently and strikingly, when, to give only one of two examples, he quotes whole sentences more or less literally from Schiller's Die Braut von Messina or Goethe's Egmont or includes parodies of Nazi-songs. Goehr, to be sure, repeatedly makes clear references to certain identifiable stylistic element from classical opera, e.g. Richard Strauß near the end of the second scene, or Leo Janacek, but by and large he seems to take his own medium more seriously than Fried and employ more subtle and individual forms of artistic expression. Those elements of parody or displays of verbal virtuosity, especially literary and musical quotations and allusions, at the same time underlined and undermined in a memorable manner the seriousness of the political implications. This difficult balance of amusement and seriousness is spelt out within the opera itself, when, after the murder of Arden, Blackwill sings :

We know it's fun at first,

A tale of much confusion

But then the bubbles burst

When death makes his conclusion.

Das fängt erst lustig an

Und geht noch oft daneben

Jedoch am Ende dann

Geht's unverhofft ans Leben.

(Vocal score, 244)

Goehr himself, as composer, takes these words as a fitting motto for his opera and thus seems to be in agreement with Paul Dessau's view that ${ }^{43}$. But, apart from one small ironic allusion to the in Brecht's , Goehr's further comments have nothing in common with Brecht's or Dessau's idea of the opera $^{44}$. He also dissociates Arden mu $\beta$ sterben from the angry young men movements well as the and insists that it is ${ }^{45}$.

Thus, the theme of has progressed from the murder story of the anonymous play and other 16th- and 17th-century texts to an image of general moral and political crisis, and in this way has evidently been brought closer to the concerns and anxieties of today's audiences, whose sympathies may not be so easily engaged for the more simply orthodox treatment of the problem of evil as portrayed in the early texts. 
Christa JANSOHN

Université de Bonn

${ }^{\text {N }}$ O T E S

1 , quoted from Catherine Belsey, , in The Subject of Tragedy. Identity \& Difference in Renaissance Drama (London, 1985), p. 136-137.

${ }^{2}$ For another approach to the topic see Kato Sadahide, , in Poetry and Drama in The Age of Shakespeare. Essays in Honour of Professor Shonosuke Ishii's Seventieth Birthday. Ed. Peter Milward, Tetsuo Anzai (Tokyo, 1982), p. 184-198. Sadahide defines evil as follows: (p. 184). The author then investigates why so many women became evil in the sixteenth-century, and then he compares six , Goneril, Lady Macbeth, Evadne (The Maid's Tragedy), Vittoria (The White Devil), Bianca (Women Beware Women) and Beatrice (The Changeling). It is a rather naive study.

See also Belsey's short interpretation of this ballad in , p. $134-135$

${ }^{4}$ According to the OED is not etymologically related to , but the two words have from the 12th century been almost synonymous.

${ }^{5}$ E.g. the following lines: , quoted from Joy Wiltenburg, Disorderly Women and Female Power in the Street Literature of Early Modern England and Germany, (Charlottesville, 1992), p. 219.

${ }^{6}$ Reading Holinshed's Chronicles (Chicago, 1994), p. 42.

${ }^{7}$ Other examples are given by Lena Cowen Orlin in her article, in Sexuality and Politics in Renaissance Drama. Ed. Carole Levin and Karen Robertson (Lewiston, 1991), p. 29-30. Cf. also Catherine Belsey, , p. 129-148.

${ }^{8}$ Quoted after Kathleen M. Davies, , inMarriage and Society. Studies in the Social History of Marriage. Ed. R.B. Outhwaite (London, 1981), p. 58-80, p. 63. Cf. also Sk. B., Counsel to the Husband; To the Wife Instruction: «A familie may bee compared vnto a commonwealth: wherein there are diuers societies and degrees, reciprocally relating, and mutually depending one vpon 
another. The highest degree or societie is between the husband and the wife ; and this is as the first wheel of a clocke, that turneth about all the rest in order. The next societie, is betweene the Parents and the children. The third betweene the seruants one with another, and towards all other superiors in the familie», quoted from Lena Cowen Orlin, Medieval \& Renaissance Drama in England, 2 (1985), 57-89, p. 64.

${ }^{9}$ Henry Smith, A Preparative to Mariage (1591), quoted from Lena Cowen Orlin, Elizabethan Households. An Anthology (Washington, D.C., 1995), p. 40.

${ }^{10} \mathrm{Cf}$. Narrative and Dramatic Sources of Shakespeare. Ed. Geoffrey Bullough, Vol. I, (London, 1977), S. 107 and The Taming of the Shrew, V.2.160-169: «Such duty as the subject owes the prince, / Even such a woman oweth to her husband, / And when she is froward, peevish, sullen, sour, / And not obedient to his honest will, / What is she but a foul contending rebel / And graceless traitor to her loving lord ? / I am ashamed that women are so simple / To offer war where they should kneel for peace, Or seek for rule, supremacy, and sway / When they are bound to serve, love, and obey».

${ }^{11}$ See also Frank Whigham,, in Ders., Seizures of the Will in Early Modern English Drama (Cambridge, 1996), p. 78-79.

${ }^{12}$ Cf. also John M. Breen, , Cahiers Élisabéthains. Late Medieval and Renaissance English Studies, 45 (1994), p. 14.

${ }^{13}$ Examples are given by Patterson (p. 215-233); she wants to show that, in view of the rather positive portrayal of women in the chronicle, one cannot simply speak of patriarchal power structures. Her chapter, though concerned with correcting omissions in other feminist accounts concerning Holinshed's images of women, surprisingly does not mention the Arden episode nor the notes to the second edition. These, however, refute Patterson's view, showing it to be no less narrowly one-sided than some of the feminist studies.

${ }_{15}^{14}$ See Patterson, p. 217-20.

15 Quoted after Lena Cowen Orlin, Private Matters, p. 16 ; her study, unlike mine, is concerned mainly with the traditional separation of public and private spheres. 
${ }^{16}$ Ed. Arthur Vincent (London, 1897), p. 32-46. Die anderen Geschichten behandeln : "Alice Perrers, Favourite of King Edward III (d. 1400), Moll Cutpurse, Thief and Receiver (? 15841659), Frances Howard, Countess of Somerset (1593-1632), Barbara Villiers, Duchess of Cleveland (1640 1709), Jenny Diver, Pickpocket (Ex. 1741), Teresia Constantia Philips (1709-1765), Elizabeth Brownrigg, Cruells personified (?1720-1767), Elizabeth Canning, Impostor (1734-1773), Elizabeth Chudleigh, Duchess of Kingston (1720-1788), Mary Bateman, (1768-1809), Mary Anne Clarke (1776-1852)» (p. vii-viii). A third edition was published in 1911

${ }^{17}$ No source is given and only the learned reader will recognise the context. The quotation comes from The Orphan : or, the Unhappy-Marriage: A Tragedy (London, 1680), where Castalio at the end of act III exclaims : «What mighty ills have not been done by women ? / Who wast betrayed the Capitol ? A Woman ! / Who lost Mark Antony the world ? A Woman! / Who was the cause of a long ten years' war, / And laid at last old Troy in ashes? A Woman! / Destructive, damnable, deceitful Woman» (1. 581-586).

${ }^{18}$ E.g. Sir Gawain and the Green Knight, I.2414ff. Cf. also Woman Defamed and Woman Defended. An Anthology of Medieval Texts. Ed. Alcuin Blamires (Oxford, 1992).

${ }^{19}$ Cf. Joy Wiltenburg, Disorderly Women and Female Power in the Street Literature of Early Modern England and Germany, p. 214. Basing her study on ca. 180 literary documents (1550-1640), Lena Cowen Orlin prefers to draw the dividing line between 1603 and 1605:, Private Matters and Public Culture in Post-Reformation England, p. 238.

${ }^{20}$ This information and other details were kindly provided by Alexander Goehr in a personal interview on the opera

${ }^{21}$ Bayan Northcott, , music and musicians, 22 (April, 1974), $26-27$, p. 26

«seine Fähigkeit, der Musik die Aussage des Wesentlichsten zu überlassen, sie zur Entfaltung aller in ihr liegender Ausdrucksmöglichkeiten anzuregen, ohne dabei jedoch auf eine gleichzeitig verständliche und bühnenwirksame, Verstand und Sinne des Hörers befriedigende Handlung zu verzichten». 
Anna Amalie Abert, , in Die Musik in Geschichte und Gegenwart. Ed. Friedrich Blume, Vol. 8 (Basel, 1960), p. 712.

${ }^{23}$ Klaus Günther Just, , in Literatur und Musik. Ein Handbuch zur Theorie und Praxis eines komparatistischen Grenzgebietes. Ed. Steven Paul Scher (Berlin, 1984), p. 100-116: «Erstens muß der jeweilige Stoff, Stoff im Sinne des Ablaufs von Geschehnissen verstanden, stark gestrafft, am besten auf einige wenige charakteristische Situationen zusammengezogen werden. Hier hat sich der Librettist als Redaktor zu bewähren. Zweitens muß im Rahmen dieser Situationen die Rede der einzelnen Gestalten dynamisiert und zugleich subtilisiert werden. Der Librettist bedarf dazu der Fähigkeiten weniger eines Dramatikers als vielmehr eines Lyrikers, der in der Lage ist, die gesamte Skala der Emotionen in knappsten Wortfügungen auszudrücken. Drittens - und das erweist sich im Laufe der Entwicklung des Opernlibrettos als der wichtigste Punkt - müssen die jeweiligen Situationen überzeugend in großräumige, konstrastreiche SchauBilder umgesetzt werden» (p. 103). [«Firstly, the particular plot, plot in the sense of the sequence of incidents, must be understood, greatly condensed, preferably reduced to some few characteristic situations. Here, the librettist has to prove himself as editor. Secondly, within the framework of these situations, the speech of the individual characters has to be made dynamic and at the same time subtle. For this, the librettist needs the gifts of the dramatist less than those of a lyric poet, who is able to express the whole range of emotions within the most compressed structure of words. Thirdly - and within the historical development of the libretto, this turns out to be the most important point - the situations to be treated must convincingly translate into large and contrasted visual images»].

${ }^{24}$ Indem das Libretto die alten Figuren übernahm oder veränderte, aber sie durchweg nach Art eines Moralitätenspiels behandelte, wurden diese Figuren, eben nach Art der alten Moralitäten lehrhaft. Ardens Hochmut gegen den ehemaligen Schneider Mosbie und die armen Schlucker Reede und Greene, Franklins Geldstolz und Härte gegen Dienstboten, besonders aber die Heuchelei der (von mir erfundenen) Nachbarsfrau Mrs. Bradshaw, die zwar ständig beteuert, gegen die Bluttat zu sein, sich 
aber gleichzeitig immer tiefer in Mitschuld verstrickt, Botengänge für die Mörder macht, ja die Mörder geradezu unwiderstehlich findet - das alles dürfte auch einem heutigen Publikum noch nicht ganz fremd sein. (Erich Fried, , p. 77).

${ }^{25}$ R.T.B., [review of Geoffry Bush, The Equation, Hugo Cole, Jonah und Goehr Arden muß sterben], Music and Letters, XLIX (July 1968), 288-290, p. 289.

${ }^{26}$ Ich arme Nachbarsfrau, - / Was sollich dazu sagen ? / Ich weiß genau, / Der Arden wird erschlagen ! / Die Zeit istnicht mehr fern : / Sie morden und sie rauben ! / Ich möchtihn warnen gern, /

Doch dann müsst ich dran glauben ! [...] Nun gut ich mach mich klein, / Ich weiß von nichts. / Man wird mir das verzeihn / Am Tage des Gerichts. / Und tadelt man mich gar / Dereinst deswegen (Geste gegen das Publikum) / So wißt ihr, es ist wahr : / Ich war schon stets dagegen! / So seh ich schweigend zu / Der Dinge bösen Lauf. (Libretto, p. 8-9)

${ }^{27}$ Guy Protheroe, , in British Music Now. Ed. Lewis Foreman (London, 1975), p 41-52, p. 47.

${ }^{28}$ Doch mit einem könnt ihr euch trösten auf eurem Heimweg :

\section{ihr selbst}

Seid nicht schuldig an Morden und auch nicht an andern Verbrechen :

Weder Täter noch Mitwisser, noch solche, die nichts

davon wissen wollten.

Und selbst wenn ihr es seid, seid ihrs nicht wie Alice

im eigenen Hause,

Sondern weit weit weg und viel besser organisiert.

$$
\text { (Libretto, p. 39) }
$$

${ }^{29}$ «die Menschen dazu (zu) bringen, Dinge, die sie für gegeben erachtet und gar nicht mehr bemerkt haben, plötzlich wieder zu bemerken, vielleicht indem wir (die Künstler) sie von einer ungewohnten Seite zeigen, oder Dinge, deren Zusammenhang sie nicht gesehen haben, jetzt zusammenzuziehen». Volker Kaukoreit, , in Text + Kritik, 91 (1986), 70-82, p. 72 and 70.

${ }^{30}$ «Es wäre aber ein Irrtum zu glauben, der Text diene nur als Anlaß zu gesellschaftskritischen Seitenhieben. Die Dramatik eines 
Textes darf durch ihre Botschaft nie erdrückt werden. Also kein , keine gewaltsame moderne Nutzanwendung ! Der Komponist und ich wußten, daß das Ganze und jede einzelne Szene uns wirklich Spaß machen mußten. Eine nur als Transportmittel für Musik oder Gedanken erträgliche Szene wäre eine mißlungene Szene». Erich Fried, , p. 78

${ }_{31}$ «It is not, of course, the case that a poet ora composer does not sometimes want, and ought to, relax or to write about something different. Indeed, it happens that oneself even sometimes gets enough of the continual horror and the continual need of opposing. A musician or a poet, like anyone else, has his weak moments. Only one must not make a virtue of this weakness, not an art that turns its back upon the world, that does not care for those human beings who are burnt in Vietnam... Twenty-one years after Hitler's death, there is an all too real danger of this, in the Federal Republic no less than in Johnson's America and in Franco's Spain». Erich Fried, Zeitdienst. Unabhängige sozialistische Information, 15 (14 April 1967), 85-86 : «Es ist natürlich nicht so, daß ein Dichter oder ein Komponist nicht manchmal auch ausspannen oder von etwas anderem schreiben will und soll. Ja es kommt sogar vor, daß das ständige Grauen, die ständige notwendige Abwehr einem selbst manchmal zuviel werden. Ein Musiker oder ein Schriftsteller hat wie jeder andere Mensch auch seine schwachen Stunden. Nur darf man aus dieser Schwäche keine Tugend machen wollen, keine weltabgewandte Kunst, der die Menschenkinder gleichgültig sind, die in Vietnam verbrannt werden... Einundzwanzig Jahre nach Hitlers Tod ist sie [die Gefahr] nur zu wirklich vorhanden, in der Bundesrepublik nicht weniger als im Amerika Johnsons und im Spanien Francos», p. 86. 1967.

${ }^{32}$ Hans G. Schürmann, Bonner Generalanzeiger, 7 March

${ }^{33}$ Gerhard Brunner, Wiener Express, 13 March 1967.

${ }^{34}$ Erich Fried interviewed on Alexander Goehr's opera Arden must Die. Interviewer Rodney Bennett, The Lively Arts Services, 19 April 1974.

${ }^{35}$ Wagner, Klaus, , p. 132.

${ }^{36}$ Hans Erdmann, ,Lübecker Nachrichten, 17 March 1967. 
${ }^{37}$ David Drew : , p. 35.

${ }^{38}$ HDC. Ebert : .

39 , Alexander Goehr : , p. 75.

${ }^{40}$ Among the British reviewers, Peter Heyworth was the only one to regret this decision. See, The Observer, 21. April 1974: «In London the epilogue has been dropped, and this change of front disconcerts me. Once created, a parable cannot be tied down to the circumstances that originally prompted it, and by withdrawing their epilogue Arden's authors awaken a comfortable suspicion that they do not mean their parable to apply to us».

${ }^{41}$ Könnte man heute - so fragten wir uns - eine Oper, die sich selbst völlig ernst nimmt, überhaupt noch ernst nehmen ? Müßte eine Oper, wenn sie dem Schicksal entgehen will, unwissentlich ihrer selbst zu spotten, diesem unbewußten Spott nicht zuvorkommen, indem sie bewußt ihre eigene Parodie wird, wenigstens zum Teil, wodurch dann ihr eigentlicher Ernst desto schärfer hervortreten könnte, durch den Gegensatz vielleicht sogar gesteigert ?», Erich Fried, , p. 75.

42 , Fritz Muggler, ,Neue Zürcher Zeitung, 15 March 1967.

${ }^{43}$ Paul Dessau, (1968), in Dessau, Notizen zu Noten (Leipzig, 1974), p. 153-157.

${ }^{44}$ Brecht's essay is reprinted in Brecht. Versuche 4-7 (Berlin, 1930), p. 107-115; for the term , see p. 109. Goehr, in the programme notes, refers to the , Act I. (p. 74). 